\title{
Erfelijkheid of vergiftigde werkelijkheid?
}

Citation for published version (APA):

van Schooten, F. J. (2002). Erfelijkheid of vergiftigde werkelijkheid? Universiteit Maastricht. https://doi.org/10.26481/spe.20020524fs

Document status and date:

Published: 24/05/2002

DOI:

$10.26481 /$ spe.20020524fs

Document Version:

Publisher's PDF, also known as Version of record

\section{Please check the document version of this publication:}

- A submitted manuscript is the version of the article upon submission and before peer-review. There can be important differences between the submitted version and the official published version of record.

People interested in the research are advised to contact the author for the final version of the publication, or visit the DOI to the publisher's website.

- The final author version and the galley proof are versions of the publication after peer review.

- The final published version features the final layout of the paper including the volume, issue and page numbers.

Link to publication

\footnotetext{
General rights rights.

- You may freely distribute the URL identifying the publication in the public portal. please follow below link for the End User Agreement:

www.umlib.nl/taverne-license

Take down policy

If you believe that this document breaches copyright please contact us at:

repository@maastrichtuniversity.nl

providing details and we will investigate your claim.
}

Copyright and moral rights for the publications made accessible in the public portal are retained by the authors and/or other copyright owners and it is a condition of accessing publications that users recognise and abide by the legal requirements associated with these

- Users may download and print one copy of any publication from the public portal for the purpose of private study or research.

- You may not further distribute the material or use it for any profit-making activity or commercial gain

If the publication is distributed under the terms of Article $25 \mathrm{fa}$ of the Dutch Copyright Act, indicated by the "Taverne" license above, 


\title{
Erfelijkheid of vergiftigde werkelijkheid?
}

\author{
REDE
}

\begin{abstract}
uitgesproken bij de aanvaarding van het ambt van Hoogleraar Genetische Toxicologie aan de Faculteit der Gezondheidswetenschappen van de Universiteit Maastricht op vrijdag 24 mei 2002
\end{abstract}

door

Dr. Frederik Jan van Schooten 


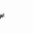


Mijnheer de Rector Magnificus,

Zeer gewaardeerde toehoorders,

In deze inaugurele rede wil ik het verleden, heden en de toekomst van de wetenschappelijke discipline van de Genetische Toxicologie bespreken. Ik zal voorspellen waar het vakgebied belangrijke bijdragen kan leveren aan de gezondheid van de mens en waar de Universiteit van Maastricht een mogelijke rol kan spelen. De Genetische Toxicologie is het vakgebied dat de interactie tussen chemische stoffen en DNA, ons erfelijk materiaal, bestudeert. Sommige chemische stoffen zijn in staat beschadigingen in het genetisch materiaal toe te brengen wat kan leiden tot de ongeremde groei van een enkele cel tot een kankercel. Als een ontspoorde cel niet vernietigd wordt door natuurlijke afweersystemen in ons lichaam dan kan deze ene kankercel op den duur uitgroeien tot een gezwel van enkele kubieke centimeters. Het lijkt tegenstrijdig maar dezelfde chemische stoffen die aan DNA binden worden gebruikt als chemotherapeutische medicijnen bij kankerpatiënten om het DNA van kankercellen te beschadigen en celgroei te remmen. Vanwege deze vergaande consequenties van de schadelijke en helende werkingen van DNA beschadigende stoffen is Genetische Toxicologie uitgegroeid tot een belangrijk vakgebied binnen de Toxicologie. Genetische Toxicologie is een grensoverschrijdend vakgebied, waarin vakken als analytische chemie, moleculaire genetica, chemische carcinogenese, cellulaire biologie, oncologie en epidemiologie samenkomen. De toekomst van de Genetische Toxicologie ligt in de vereniging van deze disciplines om tot een omvattend inzicht te komen in de effecten varn chemische stoffen op het genetisch materiaal van de mens, en de daarmee gepaard gaande kans op het krijgen van kanker en/of hart en vaatziekten. Hopelijk dat deze kennis dan gebruikt zal worden voor het schatten van gezondheidsrisico"s en de ontwikkeling van nieuwe medicijnen. 
Zoals $u$ allen waarschijnlijk wel weet krijgt niet iedereen kanker die rookt of die onder de rook van de Hoogovens woont. Hieruit valt af te leiden dat blootgesteld zijn aan de vergiffigde werkelijkheid niet altijd hoeft te resulteren tot daadwerkelijke vergiftiging en het krijgen van een ziekte. Schijnbaar is ons lichaam zeer goed in staat om met giftige stoffen om te gaan. Of we wel of niet ziek worden hangt uiteraard af van de hoeveelheid waaraan we worden blootgesteld aan giftige stoffen, maar ook van het vermogen van de mens om deze stoffen onschadelijk te maken. Het zal duidelijk zijn dat wanneer er geen blootstelling is er geen DNA schade kan ontstaan en dat bij een goede bescherming een giftige of toxische stof weinig schade zal aanrichten. De vraag is of ziekte wordt veroorzaakt door een erfelijk gebrek in de verdediging tegen blootstellingen aan chemische stoffen. Ondanks het feit dat binnen de Genetische Toxicologie onderzoek naar erfelijke achtergronden nog niet zo lang geleden is begonnen is nu al duidelijk dat meerdere erfelijke factoren gevoeligheid kunnen bepalen. Begrip van de erfelijke gevoeligheid in de omgang van chemische stoffen zal ons in staat stellen gezondheidsrisico's te beperken maar ook om de behandeling van ziekte met geneesmiddelen te verbeteren.

In het verloop van mijn lezing komen een aantal vragen aan de orde, zoals; Hoe kunnen chemische stoffen kanker veroorzaken? Welke kankerverwekkende stoffen krijgen we via woeding en roken het \ichaam binnen? Hoe gaat het lichaam met deze chemische blootstellingen om? En wat zijn de schadelijk effecten? Waarom zijn bepaalde mensen gevoeliger voor blootstelling aan kankerverwekkende stoffen dan andere mensen? Is het mogelijk via persoonsgerichte voedingsadviezen ons te beschermen tegen toxische stoffen? Op dit moment is de wetenschap nog niet zover om op alle vragen volledige antwoorden te geven. Ik zal trachten de stand van zaken weer te geven en waar mogelijk richtingen voor de toekomst te schetsen. 


\section{Achtergrond}

Kanker is na hart en vaatziekten de tweede doodsoorzaak in Nederland; jaarlijks overlijden ongeveer 40.000 mensen aan kanker. De laatste decennia is er veel kennis verkregen over hoe een normale cel verandert in een kankercel. Het is tegenwoordig duidelijk dat het kankerproces bestaat uit meerdere genetische veranderingen in de lichaamscel. Deze genetische veranderingen verstoren de besturing van de cel en zijn uiteindelijk verantwoordelijk voor de ongecontroleerde celgroei. Chemische verbindingen, maar ook radioactieve straling of virussen, zijn in staat deze veranderingen aan te brengen.

Dat invloeden van buiten af, zoals blootstelling aan kankerverwekkende verbindingen, tot kanker kan leiden is al lang bekend. De studie van de arbeidshygiëne waarin blootstelling aan chemische stoffen op de werkplek in relatie tot kanker wordt bestudeerd heeft bijgedragen tot deze kennis. Een van de eerste pioniers die een relatie legde tussen blootstelling an een chemische stof en kanker was in 1775 de arts Percival Pott in Engeland. Pott beschreef de Engelse schoorsteenvegers; kleine jongens die in de schoorstenen kropen en met hun handen de aangekoekte roet en teer verwijderden van de binnenkant. Wanneer deze jongens in de pubertijd kwamen constateerde Pott dat ze een pijnlijke ziekte ontwikkelden aan de huid van de balzak, scrotumkanker. Hij concludeerde dat deze tumoren veroorzaakt werden door de roetcleeltjes die zich door een gebrek aan een dagelijkse wasbeurt nestelden in de huidplooitjes van de balzak. Deze Engelse arts bezat een bijzondere opmerkingsgave, zeker wanneer je bedenkt dat tot ver in de $19^{\text {do }}$ eeuw dit type kanker door weel artsen gezien werd als een vorm van syfilis. Schoorsteenvegers op het Europese continent ontwikkelden niet of nauwelijks balzakkanker aangezien alhier de vakbonden gestreden hadden voor arbeidsvoorwaarden waarin het dagelijks nemen van een bad was opgenomen. 
Honderd jaar later was er een belangrijke doorbraak in het veld van de chemische carcinogenese; in 1876 werd in de medische literatuur gerapporteerd door Von Volkman dat in Duitsland asfalteerders van wegen huidkanker ontwikkelden. Min of meer tegelijkertijd zag de Schot Bell dat teer bevattende leisteenolie in mijnwerkers dezelfde ziekte deed ontstaan. Sindsdien zijn honderden rapporten verschenen waarin huidtumoren zijn beschreven bij personen na extreme blootstelling aan koolteer, pek en asfalt. Al in 1907 werden er zoveel gevallen van huidkanker in beroepssituaties gesignaleerd dat de Britse overheid het probleem onderkende en financiële compensatie bood aan hen die door deze ziekte getroffen waren. De financiële compensatie, die heel gering was, werd alleen uitgekeerd als daadwerkelijk in de 12 maanden voorafgaand aan de diagnose in de gevaarlijke omgeving gewerkt was. Men was zich toen nog niet bewust dat blootstelling aan kankerverwekkende verbindingen pas na vele jaren, soms wel 20 tot 30 jaar, tot de uiteindelijke ziekte leidt. Bovendien gaat het kankerproces door zelfs nadat de oorspronkelijke veroorzakende verbinding niet langer meer aanwezig is. Pas later is duidelijk geworden dat het kankerproces een langzaam proces van verschillende stappen is. De eerste stap is initiatie of begin, gevolgd door promotie of voortzetting, en eindigend met progressie tol verdere kwaadaardige kanker. Hoe is men tot dit inzicht gekomen?

\section{Meerstaps Proces}

De bevindingen in de mens werden ongeveer 140 jaar na Pott in 1918 onomstotelijk bevestigd in konijnenproeven door Yamagiwa en Ichikawa in Japan; konijnen ontwikkelden huidkanker nadat koolteer voor langere tijd op de oren was gesmeerd. Nadat blijkt dat niet alleen teer maar ook extracten van teer huidtumoren konden veroorzaken werd uiteindelijk rond 1930 door Kennaway en Cook in Londen de chemische stof benzo(a)pyreen geïsoleerd van koolteer. Deze verbinding bleek in staat in zuivere 
vorm en zonder aanwezigheid van andere chemische stoffen tumoren te veroorzaken in dieren. Vanaf toen was het duidelijk dat polycyclische aromatische koolwaterstoffen (PAK), waaronder benzo(a)pyreen, verantwoordelijk zijn voor de kankerverwekkende eigenschappen van teer. Sindsdien zijn grote hoeveelheden van deze stof benzo(a)pyreen in het laboratorium gemaakt en hebben vele biologische studies het werkingsmechanisme van deze stof opgehelderd.

Het kankerproces is een meerstaps proces waarin een gewone cel verandert in een zeer snel groeiende groep cellen dat organen infiltreert en die uiteindelijk vernietigen. Een kankercel groeit maar door en trekt zich niets van zijn omgeving aan. Deze kankercel gedraagt zich asociaal en is een soort hooligan die binnen het lichaam overal rotzooi schopt. De laatste 20 jaar is veel duidelijk geworden over de moleculaire veranderingen die met deze ontregeling gepaard gaan. Vlak na de tweede wereldoorlog (1947) lieten Berenblum en Shubik al zien dat huidkanker in de muis veroorzaakt door een chemische stof pas na verschillende stappen ontstaat. De eerste stap, ook wel initiatie genoend, is het resultaat van directe schade aan het DNA resulterend in kleine mar permanente veranderingen, oftewel mutaties, in genen betrokken bij de besturing van de cel. Een verandering in een gen hoeft nog niet desastreus te zijn aangezien een omvattend DNA reparatie systeem in de cel DNA beschadiging ongedaan maken. Indien echter de schade niet tijdig hersteld wordt, voordat de cel gaat delen, zal een onherstelbare mutatie ontstaan. Deze geinitieerde cel zal zich verder tot tumorcel ontwikkelen indien verdere genetische veranderingen plaatsvinden mede onder invloed van factoren die celdeling stimuleren (promotie). De verdere ontwikkeling van de tumor tot een hogere graad van kwaadaardigheid is ook afhankelijk van genetische veranderingen (progressie). Het kankerproces kenmerkt zich dus door een cascade van genetische veranderingen geinduceerd door DNA beschadigingen. Een goed voorbeeld van dit proces is het werk in de jaren 80 van Fearon en 
Vogelstein die lieten zien dat het ontstaan van dikke darmkanker in stappen gaat van goedaardig naar kwaadaardig en waarbij elke stap gekenmerkt wordt door een genetische verandering. Deze vorm van colonkanker wordt veroorzaakt door vier specifieke DNA beschadigingen in coloncellen, namelijk in een oncogen en drie tumorsuppressor genen. De kans om kanker te krijgen op jonge leeftijd is klein omdat alleen beschadigingen in bepaalde genen leiden tot kanker. Daarnaast beschikken de meeste van ons over een efficiènt reparatie systeem om DNA beschadigingen te herstellen. Dat DNA beschadigingen een cruciale rol spelen bij het ontstaan van kanker kan ook geilllustreerd worden aan de hand van mensen die een genetisch defect hebben om DNA schade te repareren. Deze mensen die de ziekte Xeroderma Pigmentosum hebben zijn niet in staat zijn om DNA schades te verwijderen zoals veroorzaakt door UV straling. Indien deze personen aan zonlicht worden blootgesteld ontstaat zeer snel huidkanker en deze mensen kunnen zich niet onbeschermd buitenshuis begeven.

\section{Epidemiologie}

Ik heb $u$ zojuist laten zien dat chemische stoffen schade kunnen berokkenen aan het genetisch materiaal van een cel. En dat de opeenhoping van genetische schades mede door het ontbreken van een goed functionerende reparatiesysteem vervolgens kan leiden tot kanker. De wetenschap die zich bezig houdt met het ontstaan van DNA schade en de gevolgen daarvan wordt de chemische of moleculaire carcinogenese genoemd. Deze wetenschap heeft belangrijk inzichten gegeven in het ontstaan van kanker. Tijdens mijn promotieonderzoek bij de Afdeling Chemische Carcinogenese van het Nederlands Kanker Instituut te Amsterdam heb ik halverwege de jaren 80 mijn eerste stappen op dit onderzoeksterrein gezet. Een ander vakgebied dat belangrijke inzichten heeft verschaft naar de factoren die van invloed zijn op kanker is de epidemiologie. Dit vakgebied bestudeert ziektepatronen in 
bevolkingsgroepen. Wij allen worden dagelijks blootgesteld aan een veelheid van kankerverwekkende stoffen vanuit voeding en omgeving en dit is geen nieuw verschijnsel. Misschien was zelfs, honderden jaren geleden, de blootstelling aan kankerverwekkende stoffen in de ongeving wel vele malen groter. Denk maar aan de indianen die veel tijd doorbrachten in met rook gevulde tenten. Voor het midden van de vorige eeuw was er echter nauwelijks enige notie dat voeding en bepaalde leefgewoonten, zoals bijvoorbeeld roken, een belangrijke invloed hadden op het ontstaan van kanker. Vanaf 1950 verschenen de eerste studies die duidelijk lieten zien dat roken verband houdt met longkanker. Het duurde echter nog geruime tijd voordät de werkelijke gevaren van roken tot de maatschappij doordrong. Een belangrijk onderzoek naar risicofactoren van kanker werd in 1.981 door de Britse epidemiologen Doll en Peto gepubliceerd. Vandaag de dag staan hun conclusies in grote lijnen nog steeds overeind. Deze was dat in de blanke mannelijke populatie sterfte ten gevolge van longkanker en andere vormen van kanker voor $30 \%$ te wijten was aan het roken van tabakswaren. Hun schatting ten aanzien van de bijdrage van voeding aan het ontstaan van kanker was minder nauwkeurig maar bleek rond de $35 \%$ in dezelfde orde van grootte te liggen. Kanker dat met werk of werkomstandigheden te maken heeft dragen in vergelijking weinig bij aan de totale kankersterfte, ongeveer $4 \%$. Studies van deze kankers hebben wel flink bijgedragen aan de kennis over chemische stoffen en ontstaan van kanker. Medicijngebruik en andere medische handelingen dragen ongeveer 3\% bij aan de totale kankersterfte. Dit percentage kan in de toekomst omhoog gaan doordat de DNA beschadigende medicijnen tweede tumoren kunnen veroorzaken nu door de verbeterde behandelingsmethoden de overlevingskansen van kankerpatiënten. zijn toegenomen. Verdere factoren zijn nog virus geïnduceerde kankers $(10 \%)$, straling geïnduceerde kankers $(2-3 \%)$, en aangeboren erfelijke factoren $(4-6 \%)$. 
Deze belangrijke studie van Doll en Peto laat de grote rol van roken en voeding zien in het ontstaan van kanker. Dat betekent met ander woorden dat een groot deel van de kankers vermijdbaar is; schattingen suggereren dat $40-75 \%$ van de kankers te voorkomen is. Laten we eens naar roken kijken. Elk jaar overlijden er in Nederland 24.000 mensen aan de gevolgen van actief roken. Bovendien sterven per jaar in Nederland ongeveer 200 mensen aan longkanker ten gevolge van het inademen van andermans rook. In de jaren voor de oorlog was roken zo gewoon dat je voor gek werd versleten als je niet rookte. In bioscoopreclames werd de lof' gezongen op de sigaret en 'met een Northstate sigaret. wordt je wel honderd jaar'. Artsen raadden zelfs roken aan ter ontspanning. Nu weten we dat dit beeld niet klopt. De levensverwachting van een roker ligt gemiddeld aanzienlijk lager dan die van een niet-roker. De jaren na de tweede wereldoorlog waren de gouden jaren voor de tabaksindustrie. In 1960 rookte in Nederland 90\% van de mannelijke bevolking. De meeste mensen zijn zich tegenwoordig wel bewust van de gevaren en zouden dus moeten stoppen met deze gevaarlijke gewoonte. Echter in de praktijk blijkt dit moeilijk haalbaar en de verslavende rol van nicotine lijkt hier een belangrijke rol in te spelen. Nog steeds rookt $39 \%$ van de mannelijke Nederlandse bevolking. Oorspronkelijk steeg onder vrouwen het percentage rokers eerst van $29 \%$ in 1960 tot ruim $40 \%$ halverwege de jaren 70 , waarna dit daalde tot $31 \%$ in 1990 . Vrouwen zijn dus later gaan roken dan mannen en als een resultaat daarvan neemt de longkanker bij vrouwen vanaf de jaren zestig sterk toe. Er zijn epidemiologische en biologische aanwijzingen dat vrouwen gevoeliger zijn dan mannen in het ontwikkelen van longkanker als gevolg van roken. In sommige landen heeft bij vrouwen de sterfte als gevolg van longkanker die van borstkanker ingehaald.

Sinds 1996 wordt er geen daling in Nederland van het percentage rokers gezien. In 1996 bedroeg het percentage volwassen rokers nog steeds $35 \%$ (mannen $39 \%$, vrouwen $32 \%$ ). Bovendien gaan de laatste jaren jongeren steeds meer roken; het gemiddeld 
percentage regelmatige rokers van $10-14$ jaar in 1991 bedroeg $7 \%$ en het steeg tot $13 \%$ in 1996 . Van de $15-19$ jarigen rookt nu $48 \%$ regelmatig. Wereldwijd neemt de incidentie van longkanker elk jaar met $0,5 \%$ toe, door een toename van het aantal rokers in ontwikkelingslanden. Roken verhoogt niet alleen de kans op longkanker maar is ook van invloed op het ontstaan van onder andere lip en tongkanker, van keel en slokdarmkanker, en van blaas en pancreaskanker. Deze cijfers stemmen niet vrolijk en laten zien dat preventie van kanker in relatie tot roken niet zo eenvoudig is te realiseren als we zouden kunnen verwachten van vermijdbaar gedrag. Het vermijden of voorkomen wan kankers die verband houden met voeding ligt zo mogelijk nog een stuk ingewikkelder. Om te overleven hebben mensen altijd voeding nodig. Bovendien is het nog niet duidelijk welke voedingsfactoren nu werkelijk de risico's verhogen. Het lijkt er wel op dat de consumptie van groente en fruit de risico's kunnen verlagen. Waarschijnlijk zijn effecten van voeding op meerdere weefsels gericht en daarbovenop zijn er aanwijzingen dat de balans tussen kankerverwekkende en kankerbeschermende voedingsstoffen belangrijk is.

Welke kankerwerwekkende stoffen krijgen we via voeding en roken het lichaam binnen? Hoe gaat het lichaam met deze blootstelling om? En wat zijn de schadelijk effecten?

\section{Een tevreden roker inhaleert}

Laten we de sigarettenroker eens als voorbeeld nemen als model van aan kankerverwekkende stoffen blootgestelde mens. De eerste vraag is dan; wat zit er in sigarettenrook dat kanker kan veroorzaken? Net zoals bij alle verbrandingsprocessen komt bij de verbranding van tabak een complex mengsel van chemische stoffen vrij. Rokers zijn voomamelijk geïnteresseerd in de verslavende stof nicotine, een bestanddeel van de tabaksplant. Echter de 
roker krijgt nog een grote hoeveelheid andere narigheden binnen. Sigarettenrook bestaat uit een mengsel van wel 4000 chemische stoffen waaronder 40 erkende kankerverwekkende stoffen. De teer en de prikkelende stoffen spelen een belangrijke oorzakelijke rol in het ontstaan van longkanker, chronische bronchitis en emfyseem.

Onder de kankerverwekkende stoffen in sigarettenrook bevinden zich stoffen die in staat zijn het DNA te beschadigen; dit worden genotoxische stoffen genoemd. Verder bevinden zich er stoffen in die via een epigenetisch mechanisme de celdeling beïnvloeden. Op pakjes sigaretten staat de hoeveelheid teer aangegeven. Teer bevat de gevaarlijke polycyclische aromatische koolwaterstoffen zoals benzo(a)pyreen. Andere genotoxische verbindingen zijn de nitrosamines en de heterocyclische aromatische amines. De genotoxische stoffen kunnen minimaal op twee manieren het DNA beschadigen. Enerzijds door interactie van de chemische stof zelf met het DNA, anderzijds via een omweg door de vorming van bijvoorbeeld zuurstofiadicalen die heftig reageren met DNA. Overigens krijgen rokers per trek aan de sigaret sowieso al veel zuurstofradicalen binnen die op deze manier direct het longepitheel beschadigen. Het belangrijkste korte termijn effect van zuurstofradicalen is het opwekken van een ontstekingsproces in de long met daaraan gekoppeld een verhoogde vermenigvuldiging van cellen die de binnenkant van de long bekleden. Dit schept een ideale omgeving voor de opwekken van kanker en de verdere uitgroei van tumorcellen. Concluderend, stoffen die het DNA beschadigen gecombineerd met stoffen die ontstekingen opwekken leiden tot een ideale situatie voor het ontstaan van kanker.

Een andere ziekte die in verband staat met roken is atherosclerose dat kan leiden tot hart- en vaatziekten. Dit verband wordt in alle grote onderzoeken gevonden en een oorzakelijk verband is zeer waarschijnlijk. Door te roken neemt het risico op een hartinfarct voor mannen en vrouwen van middelbare leeftijd toe met een factor 10. Uit epidemiologische gegevens is af te leiden 
dat roken een direct effect heeft op ontstaan en ernst van het atherosclerotische proces. De onderliggende mechanismen zijn tot nu toe nog niet opgehelderd maar directe beschadiging van de cellen van de vaatwand door toxische stoffen afkomstig uit sigarettenrook speelt een rol. Andere belangrijke veranderingen in rokers zijn waarschijnlijk vaatvernauwing en verhoging van de bloeddruk. Het goede nieuws is dat stoppen met roken leidt tot een snelle afname van het risico op atherosclerotische complicaties. Aan de andere kant blijft het risico op longkanker veel langer verhoogd nadat men is gestopt. In tegenstelling tot kanker is voor hart- en vaatziekten nog niet duidelijk welke chemische bestanddelen verantwoordelijk zijn voor de directe beschadiging van de vaatwandcellen. In de jaren 70 heeft de patholoog Benditt geobserveerd dat gladde spiercellen in de atherosclerotische plaque monoklonaal van oorsprong zijn, dat wil zeggen dat alle cellen in de plaque afstammen van maar een enkele spiercel. Dit is vergelijkbaar met een tumor waarin alle snel groeiende cellen afstammen van een enkele genetisch ontregelde of gemuteerde cel. Deze hypothese suggereert dat inademing van genotoxische stoffen een gemeenschappelijk element is in de ontstaansgeschiedenis van verschillende chromische ziektes. Ondersteunend wetenschappelijk bewijs is dat in rokers het DNA in de vaatwandcellen uitzonderlijk beschadigd is door chemische stoffen afkomstig van sigarettenrook, de schade is zelfs hoger dan in het DNA van de longcellen. Onderzoek uitgevoerd in ons laboratorium door Daniëlle Curfs in samenwerking met de vakgroep Pathologie laat zien dat benzo(a)pyreen in muizen bij voorkeur DNA schade in de cellen van de vaatwand induceert en dat de plaquevorming toeneemt mede door de sterke ontstekingsreactie in de vaatwand. Dit onderzoek kan ons inzicht verschaffen in de oorzaak en de voortgang van de ziekte, hetgeen kan leiden tot nieuwe preventieve en therapeutische strategieën. 


\section{Voeding en kankerverwekkende verbindingen}

Dat voeding een rol kan spelen bij het ontstaan van kanker is ondermeer aangetoond door epidemiologische studies van migranten. Migranten nemen vaak de soorten kanker over die in het land waarheen ze geëmigreerd zijn veelvuldig voorkomen. Bijvoorbeeld Japanners die in begin van deze eeuw in grote getale naar de Verenigde Staten emigreerden kregen in toenemende mate borst- en darmkanker tot het niveau van de Amerikaanse bevolking, terwijl deze kankersoorten weinig voorkwamen in Japan. Tegelijkertijd dalde het voorkomen van maagkanker in de geëmigreerde Japanners, wat juist weer veel voorkwam in Japan. Een kenmerk van Amerikaanse voedingsgewoonten was dat deze veel vet bevat; een 4 keer hogere vet inname vergeleken met Japan. Dit makt de inname van vet verdacht en vet wordt ook wel in verband gebracht met het ontstaan van kanker. Het precieze verband is nog onduidelijk maar DNA beschadigende reactieve zuurstof radicalen, die bij de afbraak van vetten vrijkomen, zouden een rol kunnen spelen.

Voedsel bestaat uit een veelwoud van complexe chemische stoffen afgeleid van planten, dieren en vis, gecombineerd met minuscule hoeveelheden door de mens gemaakte chemicaliën als voedingsadditieven, gewasbestrijdingsmiddelen en insecticiden. Ondanks deze complexiteit worden kankerverwekkende stoffen in voeding ook ingedeeld in genotoxische stoffen en stoffen die celgroei stimuleren. Voorbeelden van genotoxische stoffen zijn de polycyclische aromatische koolwaterstoffen en heterocyclische aromatische amines die ontstaan bij het grillen en roken van vlees en vis. Eveneens kunnen voedingsmiddelen gecontamineerd zijn met DNA beschadigende stoffen die geproduceerd worden door schimmels. Bijvoorbeeld aflatoxines, stoffen die in pindakaas kunnen zitten door schimmels die op de pindas groeien. In tropische landen zijn granen vaak met schimmels vervuild en leidt de blootstelling aan aflatoxines van deze schimmels in combinatie 
met leverontsteking tot het veelvuldig voorkomen van levertumoren. Er zijn epidemiologische aanwijzingen dat in roeding ook stoffen zitten met een beschermende werking. In het bijzonder zijn er aanwijzingen dat stoffen in groenten en fruit bescherming bieden tegen kanker. Waarschijnlijk zijn de actieve bestanddelen vezels, vitamines en andere bioactieve micronutriènten. Nog veel is onduidelijk hoe de chemopreventieve werking tot stand komt, maar van belang zijn de antioxidanten en verbindingen die de inwendige verdedigingssystemen kunnen activeren en ondersteumen.

Wat gebeurt er als genotoxische stoffen het lichaam binnenkomen? Hoe gaat het lichaam met deze blootstelling om? Waarom krijgt slechts I op de 10 rokers uiteindelijk longkanker? Zijn die andere 9 mensen op de een of andere manier beschermd tegen kanker? Waarom kon iemand als Churchill roken en drinken en toch 80 jaar worden?

\section{Vergiftigen en ontgiften}

Planten bezitten toxines ter zelfbescherming tegen vraat en met het doel de planteneter te doden. Over het algemeen zijn deze toxines verbindingen die gemakkelijk in vet oplossen en daardoor de neiging vertonen om zich in het lichaam op te hopen. Gedurende de evolutie zijn we blootgesteld geweest aan deze verbindingen en hebben hiertegen biologische verdedigingssystemen ontwikkeld. Na opname is de eerste opdracht van het lichaam on deze lichaamsvreemde stoffen te verwijderen, voordat ze gaan ophopen en voor problemen gaan zorgen. Om van de stoffen af te komen moeten ze chemisch omgezet worden tot wateroplosbare stoffen zodat ze uitgescheiden kunnen worden via de urine en de ontlasting. Twee belangrijke enzymsystemen zorgen voor deze omzetting of biotransformatie van chemische stoffen. Deze systemen zijn in de meeste cellen en weefsels aanwezig maar vooral 
in de lever en in mindere mate in de long. De eerste omzettingsreacties worden fase I-reacties genoemd, waarbij een klein molecuul in de chemische stof wordt ingebouwd. Deze reacties worden voornamelijk uitgevoerd door enzymen behorend tot familie van de cytochroom P450s (CYPs). Door de kleine verandering van de lichaamsvreemde stof kan nu de ontgifting plaatsvinden door er een lichaamseigen stof aan te koppelen. Dit worden de fase IIreacties genoemd. Na deze omzettingen is het product goed wateroplosbaar. Als voorbeelden van fase II- reacties zijn de koppeling van glutathion aan de chemische stof uitgevoerd door het enzym Glutathion-S-transferases (GSTs) en acetylering onder invloed van $\mathrm{N}$-acetyltransferases (NATs). Als alles op deze manier ontgift zou worden dan zou er een stuk minder kanker voorkomen. Maar zoals altijd is de natuur niet perfect en kunnen verkeerde wegen ingeslagen worden.

De inwerking van de CYPs of andere fase I enzymen geeft niet altijd het gewenste resultaat. In plaats van de stof te ontgiften kan het gebeuren dat de stof juist giftiger wordt. De paradox wil dat een stof als benzo(a)pyreen zelf geen reactieve groepen bezit maar juist geactiveerd kan worden tot een bijzonder reactieve verbinding met hoge affiniteit voor DNA. Kankerverwekkende verbindingen zijn dus, soms direct maar meestal pas na metabolische activering, in staat aan DNA te binden. De interactie van chemische carcinogenen met het DNA (zgn. DNA adducten) is voor het eerst in 1961 in Engeland door Brookes en Lawley aangetoond. Dit was een belangrijk moment voor het begrip van het werkingsmechanisme van kankerverwekkende stoffen. Dr. Erik Kriek, mijn copromotor tijdens mijn promotieonderzoek op het Nederlands Kanker Instituut, heeft als jonge man in het lab van de Millers in de VS in de jaren 60 cruciaal bijgedragen aan deze kennis. In de jaren 80 en 90 zijn vervolgens zeer gevoelige technieken ontwikkeld om DNA adducten in mensen te kunnen meten. Deze DNA adducten kunnen in de mens een indruk geven van blootstelling maar tevens een indicatie geven van het risico op 
kanker. Toen in 1995 Dennisenko van het lab van Pfeiffer in de VS aantoonden dat benzo(a)pyreen-DNA adducten direct verantwoordelijk waren voor de mutaties in het $p 53$-gen in longtumoren van rokers was het definitieve bewijs geleverd dat longkanker ontstaat door roken. Vandaag de dag is het niet meer mogelijk voor de tabaksindustrie zich te verschuilen achter excuses dat het bewijs louter uit epidemiologische associaties bestaat. Nog tot voor kort verklaarden woordvoerders van deze industrie dat roken "mogelijk" de kans op longkanker vergroot.

\section{Genetische verschillen in gevoeligheid}

Waarom zijn bepaalde mensen gevoeliger voor blootstelling aan kankerverwekkende stoffen dan andere mensen? De balans in activering en inactivering van chemische stoffen in het licham is bepalend voor het uiteindelijke biologische effect zoals het optreden van DNA schade en uiteindelijk het risico op kanker.

Net zoals we in deze zaal allemaal uiterlijk verschillen, zijn er ook individuele verschillen in het omgaan met chemische stoffen. Kleine genetische verschillen leiden tot grote verschillen in het vermogen om vreemde stoffen, inclusief medicijnen, te ontgitten. Deze genetische varianten worden genetische polymorfismen genoemd. Een voorbeeld hiervan is dat 6 tot $7 \%$ van de westerse bevolking een polymorfisme bezit in het CYP2D6 gen waardoor het gen niet werkt. Door het ontbreken van het CYP2D6 enzym wordt in deze mensen het verdovingsmedicijn codeïne niet omgezet in het pijnstillende morfine. Deze CYP2D6 deficiënte mensen hebben dus geen baat bij codeïne als pijnstillend medicijn. Bovendien is gepostuleerd dat deze personen gevoeliger zijn voor pijn doordat ze minder endogene opiaten aanmaken. Het toedienen van een medicijn is een voorbeeld van een blootstelling aan een enkele verbinding die ook nog eens in een hoge dosering is toegediend. In het dagelijks leven worden we echter blootgesteld aan een heleboel verschillende verbindingen in lage doseringen. 
Om de genetische varianten in relatie tot deze dagelijkse bloostellingen te bestuderen ligt natuurlijk veel ingewikkelder. Toch waren de eerste studies zo'n 10-15 jaar geleden naar genetische varianten in biotransformatie enzymen als risicofactor voor kanker veelbelovend. Zo werd in een studie door Nakachi in 1993 gevonden dat het risico op kanker verhoogd is in rokers die een sterk. benzo(a)pyreen activerend CYPIAI genotype bezitten. Het sterkste effeet werd gevonden in matige rokers; zij bezaten een 7 keer hoger risico. Dit risico werd nog eens verhoogd tot een factor 41 indien deze mensen ook nog eens het ontgiftings-enzym GSTM1 missen. Deze genetische achtergrond heeft ernstige consequenties voor de rokers. Vooral matige rokers met een ongunstig genetisch profiel hebben een aanzienlijk grotere kans op het krijgen van longkanker in vergelijking tot matige rokers met een gunstig profiel. In zware rokers is dit genetisch effect veel minder omdat hier de blootstelling zo hoog is dat een verschil in afbraak geen rol speelt; de drempel waarboven kanker ontstaat is ruim overschreden. Eigen onderzoek uit onze onderzoeksgroep uitgevoerd door Roger Godschalk heeft laten zien dat rokers die een ongunstige combinatie van de ontgiftings enzymen GST en NAT bezitten duidelijk meer DNA schade in hun bloedcellen hebben. De vraag is dan natuurlijk; zijn dat dan juist de mensen die uiteindelijk kanker krijgen? Onlangs is in een studie, uitgevoerd door de groep van Perera in New York, inderdaad gebleken dat de mensen met hoge DNA adduct waarden in het bloed degene waren die longkanker kregen. Het is dus duidelijk dat DNA schade slecht is en dat het meten van DNA schade in de mens een goede benadering is om in een vroeg stadium te bepalen of preventieve acties gerechtvaardigd zijn, bijvoorbeeld via voeding. Binnen onze onderzoeksgroep is veel ervaring in de analyse van DNA schade en moleculaire markers van gevoeligheid. De komende jaren zullen we een belangrijke bijdrage kunnen leveren aan het preventief voedingsonderzoek. 
Een andere voorbeeld van de rol van voeding in kanker is het ontstaan van dikke darmkanker door het veelvuldig nuttigen van goed doorbakken wlees. Het bakken en braden van vlees kan leiden tot het ontstaan van kankerverwekkende verbindingen genaamd heterocyclische aromatische amines (HAAs). Deze verbindingen worden tot reactieve verbindingen omgezet 0. a. door CYP1A2 en NAT2. In een studie uitgevoerd door Lang en medewerkers in 1994 werd gevonden dat mensen met een genotype waarbij deze enzymen een hoge activiteit hebben, een verhoogd risico op kanker hebben na het eten van doorbakken vlees. Het lijkt er dus op dat deze gevoeligheidsgenen een rol kunnen spelen bij de kankers die veroorzaakt worden door exogene factoren zoals door Doll en Peto beschreven. Inmiddels is er veel onderzoek gedaan naar gevoeligheidsgenen in relatie tot kanker. Na de eerste studies waarin sterke verbanden gevonden werden zijn in vervolgstudies niet altijd dezelfde resultaten verkregen. Van twee enzymen staat wel onomstotelijk vast dat ze een rol spelen in kanker, namelijk; (1) ontbreken van GSTMI in relatie tot longkanker en (2) langzaam NAT2 acetylering in relatie tot blaaskanker. Dat geen duidelijke verbanden gevonden worden tussen genetische varianten in metaboliserende genen en algemene effecten, zoals kanker, is niet verwonderlijk. Immers de ontwikkeling van kanker staat onder invloed van heel veel verschillende oorzaken en verloopt via een groot aantal biochemische routes. De genen spelen slechts een specifieke biochemische rol in een van die wegen van het kankerproces. Desondanks zijn in kleine goed omschreven groepen uit de bevolking de verbanden soms sterk terwijl ze in de totale bevolking niet of nauwelijks te vinden zijn. Goede voorbeelden zijn de eerder genoemde matige rokers en doorbakken vleeseters; subgroepen waarin een duidelijk verband was tussen genetische polymorfismen en kanker. Om tot betere onderverdelingen te komen zal het noodzakelijk zijn grootschalige moleculair epidemiologische studies uit te voeren. Grootschalig omdat dan subgroepen bestudeerd kunnen worden ingedeeld op mecha- 
nistische en rationele gronden. Zoals gezegd is het dus verklaarbaar dat een enkele genvariant geen grote rol heeft in gevoeligheid voor een algemene vorm van kanker. Daarom zijn de recente studies die zwakke verbanden laten zien tussen een gen en kanker niet teleurstellend maar bevestigen ze juist de inzichten aangaande carcinogene mechanismen en de rol van metabolle genen. Om meerdere genen tegelijkertijd te bestuderen in de interactie met voeding en omgeving zijn grootschalige epidemiologische studies nodig.

\section{Stoppen met roken is geen eenvoudige zaak}

Dat het roken van sigaretten schadelijk kan zijn weet tegenwoordig iedereen. De praktijk heeft wooral in de VS geleerd, dat de algemene waarschuwingen op de televisie en in de krant plus de teksten op de pakjes niet veel uithalen. Zelfs hardere taal. is niet in staat om de mensen te doordringen van de gevaren. De meeste rokers continueren hun rookgewoonten en veel jonge mensen starten met het roken van sigaretten. Waarom? Dat het percentage rokers niet meer daalt is waarschijnlijk mede te wijten aan een grote mate van verkrijgbaarheid en de toename van tabaksreclame in de laatste jaren. Echter, de werkelijke oorzaak is dat nicotine in de sigaret sterk verslavend is, minstens zo verslavend als cocaïne en heroïne volgens verslavingsdeskundigen. De voorlichting over de gevolgen van roken, waaraan jaarlijks een bedrag wordt uitgegeven dat minder is dan 10 miljoen gulden, kan hier niet tegen op. Van alle mensen die op eigen gelegenheid stoppen slaagt maar $10 \%$ het langer dan éen jaar vol te houden. Ondersteuning bij het stoppen door gebruikmaking van nicotine vervangers in de vorm van nicotinepleisters, -kauwgum en inhalalie van nicotine helpt wel enigszins, maar succespercentages komen niet boven de $20 \%$ uit.

Inademen van sigarettenrook is vanwege het grote oppervlak van de longen een ideale manier om nicotine snel naar de 
hersenen te transporteren; $90 \%$ wordt in de longen opgenomen waarvan eenderde binnen 10 seconde de hersenen bereikt. Deze korte tijdsinterval tussen roken en het effect wordt wel gezien als verantwoordelijk voor de conditionerende respons en verslavende werking van nicotine. Rokers zijn zeer goed in staat zich zelf te drogeren door de hoeveelheid nicotine in hun bloed op een constant niveau te houden. Na het roken van een sigaret daalt de hoeveelheid nicotine in het bloed in anderhalf à twee uur met de helft. Komt de nicotine concentratie onder een bepaald niveau dan is er weer behoefte aan een nieuwe sigaret. Vandaar ook dat rokers s'ochtends na een lange sigaretloze nacht de eerste sigaret enorm waarderen. Nicotine wordt afgebroken in de lever door oxidatie tot de belangrijkste inactieve metaboliet, cotinine. Deze omzetting van nicotine gebeurt hoofdzakelijk door het enzym CYP2A6. Dit enzym is in de bevolking aanwezig in verscheidene genetische vormen die in activiteit verschillen. Recente studies laten zien dat mensen met actieve CYP2A6 enzymen sneller nicotine afbreken en daarom ook makkelijker aan nicotine verslaafd raken, en meer sigaretten per dag consumeren. Hier ligt een mogelijkheid om via de onderdrukking van CYP2A6 door middel van remmers, via medicatie of voeding, verslavingsgevoelige mensen te ondersteunen in hun poging te stoppen. Recente wetenschappelijke studies laten bemoedigende resultaten zien. Tweelingenstudies toonden aan dat naast omgevingsfactoren genetische factoren een sterke rol spelen bij het starten met roken en het vervolgens verslaafd raken. Het wordt langzaam duidelijk welke genetische factoren en biochemische routes hierbij betrokken zijn. Het in kaart brengen van deze factoren kan leiden tot het ontrafelen van de erfelijke factoren betrokken bij verslaving. Dit kan mogelijk leiden tot persoonsgerichte interventies door psychologische technieken en medicijnen.

Het is een utopie te verwachten dat het ooit zal lukken een rookvrije of verslavingsvrije maatschappij te scheppen door sociale druk via de overheid of de samenleving. In de laatste jaren wordt het duidelijk dat sigarettenverslaving een complexe aan- 
doening is. Toen ongeveer anderhalf jaar geleden een samenwerking tussen onderzoekers van Maastricht en Wageningen werd gepresenteerd waarin een 'veiliger' sigaret werd beschreven laaide de discussie in de media hoog op. De onderzoekers berekenden dat indien alle Nederlandse rokers op deze sigaret zouden overstappen jaarlijks 5200 minder doden zouden vallen. De onderzoekers ontwikkelden een filter dat minder PAKs en teer doorliet maar tevens de hoeveelheid nicotine reduceerde. Het verlagen wan de nicotine-en teergehalte in de tabak zelf is al eerder toegepast. Dit biedt echter geen soelaas omdat een roker dan alleen maar meer sigaretten gaat roken of dieper gaat inhaleren om toch het nicotine gehalte in de hersenen op peil te houden. De kunst is wel de nicotine af te leveren maar niet de kankerverwekkende stoffen en dat lijkt nog een brug te ver. De industrie probeert rooklloze sigaretten te ontwikkelen, en de alternatieve toediening van nicotine in kauwgom, pleisters, neusspray en inademing uit nepsigaretten als ondersteuning bij het stoppen met roken is al geruime tijd in gebruik. Wij moeten niet bij voorbaat iedere poging om de sigaret te vervangen veroordelen, maar gezien de recente ervaringen zijn grote verwachtingen niet gerechtvaardigd. Hoe ethisch is het nu om rokers buiten te sluiten van medisch handelen of medisch onderzoek naar ziektes als gevolg van tabaksverslaving te beperken. Gezien alle nieuwe inzichten in de erfelijke bijdrage aan nicotineverslaving zou een dergelijk handelen geen recht doen aan de complexiteit van deze verslaving. Eenzelfde discussie is gevoerd in de begindagen van de AIDS epidemie toen sommige groepen in de samenleving van mening waren dat AIDS patiënten het aan zichzelf te danken hadden en daarom geen recht hadden op de volle ondersteuning van de samenleving. Gelukkig was het resultaat van deze discussie solidariteit met AIDS patiënten en enorme inspanningen tot het vinden van geneesmiddelen en grote voorlichtingcampagnes gericht op voorkoming van HIV infecties. 


\section{Op maat gesneden voedingsadviezen}

Zal in de toekomst de arts een genetisch profiel van de patient samenstellen en dan advies uitbrengen wat iemand wel en niet mag eten, drinken, roken, en bewegen om gezond te blijven? In de naaste toekomst is het te verwachten dat medicijngebruik afgestemd zal worden op de genetische achtergrond van de patiënt. Zijn echter ook op maat gesneden voedingsadviezen te verwachten? Recentelijk is een bedrijf gestart in Engeland dat pretendeert op maat gesneden voedingsadviezen te geven. Dit bedrijf heeft pakketten in de Body Shop liggen waarin informatie over genetische achtergronden; een vragenlijst naar voedingsgewoontes en levenswijze, en borsteltjes om wangcellen te verzamelen. Men kan deze pakketten kopen en de ingevulde vragenlijst samen met de wattenstaafjes met afgeschraapte wangcellen opsturen naar het bedrijf. $\mathrm{Na}$ ontvangst isoleert het bedrijf het DNA van de wattenstaafjes en bepaalt de genetische polymorfismen in de enzymen betrokken bij activering en ontgifting van gevaarlijke chemische stoffen (CYPIAI, NAT1, NAT2, GSTM1, GSTTI en GSTPI), antioxidant afweer (MnSOD), alcohol afbraak $(A L D H 2)$ en weefselherstel (MTHFR). Zoals eerder gezegd zijn dit genetische varianten die een laag risico met zich mee brengen. Mutaties die een sterk verhoogd risico impliceren zoals in genen betrokken bij Alzheimer of borstkanker worden niet bekeken. Niemand zal dramatisch nieuws krijgen. Via internet heb ik een pakketje besteld, meteen wangcellen geschraapt, enquête ingevuld en het hele handeltje opgestuurd naar het bedrijf. Het aanleveren van het genetisch monster is vrij gemakkelijk; je schraapt met een klein borsteltje de binnenkant van je wang gedurende een minuutje en stopt het in een plastic buisje. Moeilijker is het invullen van de "lifestyle questionnaire"; het beantwoorden van 90 vragen waaronder gedetailleerde vragen over de frequentie van het nuttigen van bepaalde voedingsmiddelen met daaraan gekoppeld de bereidingswijze. Bijvoorbeeld, zes vragen over de consumptie van rood 
vlees. Na drie weken kreeg ik een 30-pagina verslag dat op basis van mijn genetisch profiel een voedingsadvies bevat. Dit grapje kost 120 engelse ponden; een aardig gepeperde prijs.

Wat was mijn uitkomst? Ik moet meer knoflook en uien eten. Meer groene groentes, en af en toe lever. Over het geheel genomen heb ik twee ongunstige genetische varianten. Dat valt weer mee. Elk van de varianten bevindt zich in 20 tot 40 procent in de bevolking, hetgeen betekent dat een gemiddeld persoon voor vijf of zes positief zal zijn. Met iedereen is wel wat aan de hand. Mijn eerste polymorfisme is in het gen voor een enzym genaamd methylene tetrahydrofolate reductase, afgekort als MTHFR. Dit enzym stelt het lichaam in staat om foliumzuur, een belangrijke component in voedsel, te gebruiken om DNA in groeiende cellen aan te maken. We hebben twee kopieën van de meeste genen, van beide ouders een, en een van mijn MTHFR genen is niet functioneel. Als gevolg daarvan heb ik slechts $65 \%$ van de normale MTHFR activiteit. Foliumzuur is van essentieel belang voor de cellulaire replicatie en celdeling. Het typische westerse dieet voorziet niet in voldoende foliumzuur en daarom, mede gezien mijn MTHFR mutatie, krijg ik als advies om meer foliumzuur te nuttigen en gerelateerde B vitamines. Lever is een voedingsmiddel met veel foliumzuur, en het is ook aanwezig in rood vlees en aan sommige voedingsproducten is het toegevoegd. Het tweede polymorfisme is in het gen voor mangaan superoxide dismutase, of afgekort MnSOD, een antioxidant enzym dat cellen beschermd tegen de schadelijke werking van vrije radicalen. Dit betekent dat ik meer voedsel moet eten met natuurlijke antioxidanten, in het bijzonder vers fruit en groentes, uien en knoflook. Ik werd verder gerustgesteld dat ik geen polymorfismen bezit in de genen betrokken bij de verwijdering van toxische stoffen uit het lichaam (GSTs en NATs). Dit betekent dat ik rustig doorgebakken biefstukken kan blijven eten en gerookte zalm. En ook gegrilde hamburgers. Bijzonder opgelucht was ik eveneens on te horen dat ik twee normale kopieën heb van het aldehyde dehydrogenase II 
gen, welk een belangrijke rol speelt bij de afbraak van alcohol. Dus drinken van alcohol zal me niet zo snel vergiftigen dan wanneer ik in dit gen een polymorfisme zou hebben. De receptie kan ik dus met vertrouwen tegemoet zien.

Zijn dit nu zinvolle adviezen? Wetenschappelijk gezien is het nog te vroeg om deze op de persoon gerichte voedingsadviezen te geven. Er zijn wel studies die bemoedigende resultaten laten zien. Bijvoorbeeld dat kruisbloemige groenten zoals broceoli, bloemkool en kool beschermend kunnen werken ten aanzien van longkanker en dat vooral personen die het ontgiftings-enzym GSTM1 missen de meeste baat hebben bij verhoogde consumptie van deze groenten. Een resultaat dat hiermee overeenstemt vonden wij in samenwerking met het Nederlands Kanker Instituut; in een interventie studie met de beschermende stof $\mathrm{N}$-acetylcysteine in rokers zagen we in rokers die het ontgiftings-enzym GSTM1 missen de meeste reductie van genetische schade in de longcellen. Ondanks deze resultaten zijn er naar mijn mening nog teveel onduidelijkheden over de impact van genetische varianten op ziekte en de interactie van voeding hierop. Ik zou de meer algemene adviezen willen aanbevelen. In 1997 kwam een lijvig rapport uit van de World Cancer Research Fund en de American Institute for Cancer Research met onder andere de volgende aanbevelingen; eet gevarieerd; nuttig tussen de 400-800 gram, of minimaal 5 porties, groente of fruit; beperk alcohol consumptie tot maximaal twee drankjes per dag voor mannen en een drankje per dag voor vrouwen; beperk rood vlees tot minder dan 80 gram per dag; vermijd overgewicht en beweeg minimaal een uur per dag. In zijn algemeenheid heeft dus iedereen baat bij het advies om gevarieerd te eten, niet te vet, veel vers fruit en groente, niet te roken en matig te drinken. De genetisch gebaseerde adviezen voegen hier nog niet veel aan toe. Bovendien kan het uitnodigen zich eenzijdig te richten op enkele voedingscomponenten om het zogenaamde genetische gebrek te compenseren terwijl juist gevaricerde voeding te prefereren is. Nog even voor de duidelijkheid; bovenstaande is 
niet mijn werkelijke genetische profiel maar de casus heeft slechts als voorbeeld gediend. I $k$ wil echter niet dezelfde berichten in de krant krijgen zoals toen onlangs uitkwam dat de DNA-code van het menselijke genoom, die twee jaar geleden door het Amerikaans bedrijf Celera werd onteijferd, gebaseerd bleek op het erfelijk materiaal van de voormalige directeur van het bedrijf, Graig Venter.

\section{Toekomstig onderzoek}

Chronische ziekten, zoals bijvoorbeeld kanker en hart- en vaatziekten, zijn te beschouwen als een ijsberg. Alleen het topje van de ijsberg is zichtbaar. Maar de grootte van de ijsberg wordt bepaald door hetgeen zich onder het wateroppervlak afspeelt. Kanker drijft spreekwoordelijk in een koude zee van risicofactoren en is onderhevig aan een warme stroom van beschermende factoren. Of de ijsberg zal smelten of juist zal aangroeien hangt af van zijn omgeving maar ook van zijn eigen inwendige hardheid. Wat speelt zich onder het oppervlak af? Dat is de vraag die beantwoordt dient te worden om personen met verhoogd risico te kunnen identificeren en zinvolle adviezen ter preventie te kunnen geven. De meeste chronische ziekten kenmerken zich door de betrokkenheid van meerdere genen en omgevingsfactoren. Een multidisciplinaire benadering is nodig om het complete beeld te krijgen. Epidemiologen zijn nodig om de relatie tussen zeestromen en ijsberg zichtbaar te maken, chemici om de stromen te analyseren, biochenici en moleculair biologen om het proces van aangroei en afkalving in kaart te brengen, en ten slotte om de inwendige hardheid te bepalen zijn de genetici nodig. Het op een lijn brengen van deze disciplines zal de uitdaging zijn van de komende jaren.

Sinds de ontrafeling van bet menselijke genoom in het jaar 2000 is de ijsberg in een moleculaire storm terechtgekomen. Het genoom is de totale verzameling van alle genen, dus van alle erfe- 
lijke informatie. Het grootste deel van de genen, ongeveer 35.000 verschillende, is nu bekend. Met deze kennis is het mogelijk om de samenhang tussen genen, hun genproducten, en de interactie met de omgeving in detail in kaart te brengen. Technologische ontwikkelingen spelen hierin een belangrijke rol. Dit nieuwe onderzoeksveld wordt genomics ofwel genomica genoemd. Momenteel is het mogelijk met geavanceerde technieken in korte tijd een gedetailleerde analyse van het genetische materiaal krijgen. Dit kan zowel op het nivo van het tussenproduct het RNA (transcriptomics) als wel op het eindproduct de eiwitten (proteomics). Op het nivo van de chemische stoffen en de metabolieten wordt het onderzoek metabolomica genoemd. Met deze genomica technieken kunnen we in detail bestuderen hoe een cel reageert op de blootstelling aan een toxische stof. Deze benadering geeft tot nu toe ongekende mogelijkheden om potentiële voor de mens gevaarlijke stoffen te identificeren en de blootstelling te evalueren. In de toekomst kunnen we een compleet beeld verwachten van welke genen betrokken zijn bij het door chemische stoffen geïnduceerde kankerproces, en welke afwijkingen in genen de individuele gevoeligheid bepaalt. Hooggespannen zijn de verwachtingen dat deze nieuwe technologieẻn zullen leiden tot 1) nieuwe groepen van biomarkers die voorspellen of een beschadiging zal uitmonden in kanker, 2) beter begrip van genetische veranderingen door toxische stoffen, 3 ) beter inzicht in de rol van voeding en omgevingsfactoren op ziekte.

Zoals ik heb laten zien is het begrijpen van erfelijke factoren in relatie tot gevoeligheid voor chemische stoffen belangrijk om individuele risico's te kunnen inschatten. Het DNA van verschillende individuen is maar voor $0,01 \%$ verschillend, oftewel het DNA van mensen is $99,99 \%$ identiek. Het is onduidelijk hoe zulke kleine verschillen in erfelijk materiaal tot zulk een variëteit in menselijke gevoeligheid voor chemische stoffen en uiterlijk kan leiden. Dat kleine verschillen in DNA grote consequenties kunnen hebben is duidelijk als men beseft dat het DNA van de 
mensapen en mensen $99 \%$ identiek is. Tot op heden zijn 1.4 miljoen "single nucleotide polymorphisms", of "SNIPs", geïdentificeerd. Zoals gezegd kan een combinatie van een aantal "ongunsti$\mathrm{ge}^{*}$ SNIPs een verhoogd risicofactor voor kanker betekenen. Het is alleen nogelijk om meerdere combinaties te bestuderen in onderzoekspopulaties van duizenden personen en vraagt nauwe samenwerking met Epidemiologen en Populatiegenetici. In Maastricht is een unieke situatie met sterke vakgroepen in deze twee disciplines. Om dergelijk grootschalig onderzoek te verwezenlijken zijn we in samenwerking met her Genoom centrum in Maastricht methodieken aan het ontwikkelen voor grootschalige analyse wan genen betrokken bij aanval en afweer.

Als eenmaal deze methodieken en technieken zijn toegepast dan zal de volgende stap zijn om de ingewikkelder bijdrage van de ongeving en of voeding op kanker te bepalen. Het onderzoek in onze capaciteitsgroep Gezondheidsrisico Analyse en Toxicologie is gericht op de ontwikkeling van moleculaire metingen (biomarkers) in de mens die iets kunnen zeggen over blootstelling aan toxische stoffen en gevoeligheid van ziekte. De relatie tussen voeding en kanker is nog steeds in duisternis gehuld. Deze duisternis kunnen we als een blackbox voorstellen; je stopt er iets in, en er komt ook iets uit, maar je weet niet precies wat er in de blackbox gebeurt. Mechanistisch onderzoek is nodig om deze blackbox in te vullen. Nodig zijn methoden en technieken om blootstelling aan voedingscomponenten te bepalen door metingen in bijvoorbeeld urine en bloed; het ontwikkelen van biomarkers die iets kunnen zeggen over mechanistische biochemische routes; en begrip van genetische gevoeligheid. Naar mijn mening kunnen we vanuit de Genetische Toxicologie in Maastricht een unieke bijdrage leveren door bestudering van de moleculaire markers die de relatie tussen blootstelling en ziekte in kaart brengen en als tussenmeting kunnen fungeren om te zien of preventieve acties succesvol zijn. 
De situatie in Maastricht is veelbelovend. De Universiteit Maastricht en het Academisch Ziekenhuis (AZM) hebben het initiatief genomen om het moleculaire onderzoek te versterken door de krachten te bundelen, de Brede Onderzoeksstrategie (BOS) genoemd. Door dit initiatief bezitten we nu in Maastricht een Genoomcentrum, Proteoomcentrum, Transgene dieren Unit, en nieuwe leerstoelen op het gebied van de Populatiegenetica en Moleculaire Genetica, Functionele Genetica en de Genetische Toxicologie. Een andere belangrijke ontwikkeling is de onlangs gesmede alliantie tussen de UM en het Limburgs Universitair Centrum in Hasselt-Diepenbeek, resulterend in de transnationale Universiteit Limburg (tUL). Binnen de tUL gaan we in september aanstaande met de nieuwe opleiding Moleculaire Levenswetenschappen van start. De opleiding is in een Bachelor-Master structuur gegoten en behandelt het gehele traject van gen tot gezondheid. Er is de afgelopen tijd door veel docenten van beide instel. lingen hard gewerkt en er ligt een bijzonder interessant onderwijsprogramma klaar. Hier ligt een uitdaging om jonge mensen voor ons boeiende vak te enthousiasmeren. Het vakgebied heeft gedreven mensen nodig die bereid zijn om hard te werken om onze internationale positie in het biomedisch onderzoek te versterken. Mijn droom voor de Genetische Toxicologie is dat op de Universiteit van Maastricht een klimaat geschapen wordt waarin werkelijk fundamenteel en vernieuwend onderzoek mogelijk is. Tegelijkertijd dient het belang van goed onderwijs in de gaten gehouden te worden. Zoals gezegd is het voor wetenschappers van eminent belang om studenten en promovendi op te leiden en voor het onderzoek te behouden. Vernieuwend onderzoek wordt vaak juist door hen verricht.

Dames en heren, de meeste van ons hebben ooit wel eens in de naaste omgeving met kanker te maken gehad. Dat roept vele vragen op. Ongetwijfeld ook de vraag; waarom is nu juist deze ene persoon door de ziekte getroffen? Is het een resultaat van de 
vergiftigde werkelijkheid en zijn er ook erfelijke factoren bij betrokken? Om deze vraag te kunnen beantwoorden zijn inzichten in oorzaken en achterliggende mechanismen nodig. Ik hoop dat ik $\mathrm{u}$ vandaag enkele van deze inzichten verduidelijkt heb, en ook hoe er op sommige van de nog openstaande vragen een antwoord gegeven kan worden.

\section{Dankwoord}

Aan het einde van deze rede gekomen wil ik nu graag een aantal personen bedanken die hebben bijgedragen aan het feit dat ik hier nu sta.

Allereerst wil ik de Faculteit der Gezondheidswetenschappen en het College van Bestuur bedanken voor het in mij gestelde vertrouwen bij mijn benoeming als hoogleraar. In het bijzonder wil ik ook de benoemingsadviescommissie bedanken. Zoals in mijn betoog gézegd is de Genetische Toxicologie een vakgebied waarbij niet alleen met vakgenoten wordt samengewerkt maar ook met onderzoekers van andere disciplines. Ik zie er naar uit naar deze samenwerkingen binnen de Universiteit Maastricht, het Academisch Ziekenhuis en de transnationale Universiteit Limburg. En niet te vergeten zie ik ook uit naar de samenwerkingen met de nationale en internationale collega's.

Mijn carrière begon bij de afdeling Chemische Carcinogenese van het Nederlands Kanker Instituut in Amsterdam. Hier heb ik de eerste stappen in het wetenschappelijk bedrijf gezet onder deskundige leiding van Erik Kriek. Hij is een wetenschapper die integer, nauwgezet en met grote kennis van zaken de wetenschap bedrijft. Bedankt voor het vele dat ik van je geleerd heb en voor al je steun en vriendschap.

Zonder Jos Kleinjans had ik ongetwijfeld nooit de overstap naar Maastricht gemaakt. Hij heeft me doen inzien dat de groeimogelijkheden in Maastricht aanwezig waren. Het is inderdaad snel gegaan; eerst een tijdelijke aanstelling, vervolgens universi- 
tair docent in waste dienst en daarna universitair hoofddocent binnen de capaciteitsgroep Gezondheidsrisico Analyse en Toxicologie. En nu dit. Bedankt voor alle hulp die je me gegeven hebt en ik hoop in de toekomst nog veel samen te werken.

Alle collega's van de capaciteitsgroep Gezondheidsrisico Analyse en Toxicologie, uitzonderlijke dank voor jullie loyaliteit, inzet en medewerking. Zonder jullie stond ik hier nu niet. Verder wil ik de collega's van het onderzoeksinstituut NUTRIM bedanken voor de samenwerking en alvast voor toekomstige samenwerkingen.

Mijn Amsterdamse studievrienden wil ik bedanken dat julllie me niet gevolgd zijn naar Maastricht. Als jullie me wel gevolgd waren had ik hier nu misschien niet gestaan. Zonder jullie is het een stuk rustiger maar ik moet toegeven ook wel een stuk saaier. Ik kijk nu alweer uit naar het komende ouwelullen weekend op de waddeneilanden. Het doet me plezier om na Ron nu de tweede professor in onze vriendenkring te zijn.

Mijn een na laatste dankwoord gaat uit naar mijn lieve moeder, mijn broers en zussen. Ik ben opgegroeid in een rumoerig en gezellig gezin met 7 kinderen. De meeste van ons zijn later naar Amsterdam getogen waar we ook weer veel met elkaar hebben opgetrokken. Vervolgens zijn we weer verder uitgevlogen maar nog steeds is de band heel hecht. Zeker op een dag als deze blijft het jammer dat mijn vader hier niet meer is.

Als laatste wil ik Karin bedanken. Gelukkig ben je 11 jaar geleden meegegaan naar Maastricht. Je hebt me al die tijd onvoorwaardelijk gesteund en zonder die steun was dit me nooit gelukt. En dan natuurlijk Frits en Jelle. Als het aan jullie had gelegen hadden we toch beter in Amsterdam, de stad van jullie geliefde Ajax, kunnen blijven. Laten we hopen, voor jullie, dat er nog eens een FC Limburg komt. Bedankt jongens.

Ilk heb gezegd. 